\title{
Metal-induced tautomerization of oxazole and thiazole molecules to heterocyclic carbenes $\dagger$
}

\author{
Javier Ruiz* and Bernabé F. Perandones \\ Received (in Cambridge, UK) 16th January 2009, Accepted 27th February 2009 \\ First published as an Advance Article on the web 23rd March 2009 \\ DOI: $10.1039 / b 900955 h$
}

Oxazole and thiazole molecules $N$-coordinated to manganese(I) are transformed into their corresponding 2,3-dihydrooxazol-2ylidene and 2,3-dihydrothiazol-2-ylidene carbene tautomers by acid-base reactions, and subsequently transmetalated to gold(I), via isolable heterometallic intermediates.

Oxazole (1a) and thiazole (1b) are simple molecules of great relevance in heterocyclic chemistry and important structural elements in many natural products. ${ }^{1}$ Their corresponding carbene tautomers, 2,3-dihydrooxazol-2-ylidene (2a) and 2,3-dihydrothiazol-2-ylidene (2b), derived from a 1,2-hydrogen shift (Scheme 1) are not stable, and this has been rationalized on the base of theoretical calculations, ${ }^{2}$ deuterium exchange NMR measurements ${ }^{3}$ and argon matrix experiments. ${ }^{4}$ On the other hand, whereas a large number of NHC complexes of imidazol-2-ylidene type are known, ${ }^{5}$ many of them successfully applied in homogeneous catalysis, ${ }^{6}$ relatively few examples of coordination complexes containing carbene ligands of oxazol2-ylidene or thiazol-2-ylidene types have been described. Methods for preparing oxazol-2-ylidene carbene complexes are limited to intramolecular cyclization of functionalized hydroxy isocyanides ${ }^{7}$ or reaction of epoxides with hydrogen isocyanide complexes, ${ }^{8}$ the classical route involving in situ deprotonation of oxazolium salts being very infrequently encountered in the literature. ${ }^{9}$ A rare case of cyclization of ketones with coordinated isocyanide has been described. ${ }^{10}$ Thiazol-2-ylidene carbene complexes are frequently prepared by reaction of lithiated thiazoles with the appropriate metallic fragment and subsequent alkylation or protonation of the corresponding thiazolyl derivative. ${ }^{11}$ Methods implying in situ deprotonation of thiazolium salts have also been used. ${ }^{12}$ Whereas complexes containing carbene $\mathbf{2 b}$ are known, ${ }^{11 b}$ to the best of our knowledge, so far there has been no report of a complex containing the oxazolin-2-ylidene carbene 2a itself. We have recently reported that coordinated imidazoles can be transformed into their corresponding NHC complexes by means of acid-base treatments. ${ }^{13}$ We have now found that this methodology can be applied to oxazole (1a) and thiazole (1b) molecules coordinated to manganese(I), which can easily be converted to oxazolin-2-ylidene (2a) and thiazolin-2-ylidene (2b) ligands, respectively. Preliminary results on the use of

Departamento de Química Orgánica e Inorgánica, Facultad de Quimica, Universidad de Oviedo, 33006 Oviedo, Spain.

E-mail:jruiz@uniovi.es; Fax: + 34985103446; Tel: + 34985102977

$\dagger$ Electronic supplementary information (ESI) available: Experimental details and analytical and spectroscopic data. CCDC 716673 (4b), $716674(\mathbf{6 b}), 716675$ (7b) and $716676(\mathbf{8 b})$. For ESI and crystallographic data in CIF or other electronic format see DOI: 10.1039/b900955h these complexes as carbene transfer agents are also shown herein.

Azoles 1a,b easily coordinate to $\mathrm{Mn}(\mathrm{I})$ when reacting with the precursor complex fac-[ $\mathrm{Mn}\left(\mathrm{OClO}_{3}\right)(\mathrm{CO})_{3}$ (bipy)] (3) to afford the cationic complexes $\mathbf{4 a , b}$ (Scheme 2). As can be seen in the X-ray diffraction study carried out on $\mathbf{4 b}$ (Fig. 1) $\ddagger$ the azole ligands in these complexes are $N$-coordinated. $\mathbf{4 a , b}$ are readily deprotonated at the $\mathrm{C} 2$ carbon atom of the azole heterocycle when treated with $\mathrm{K}^{t} \mathrm{OBu}$ to afford neutral derivatives $\mathbf{5 a , b}$ containing oxazolyl and thiazolyl ligands. Subsequent protonation at the nitrogen atom gives the carbene complexes $\mathbf{6 a}, \mathbf{b}$ in quantitative yields, completing the metal and acid-base induced tautomerization of the original azole molecules 1a,b. It should be mentioned that a low yield transformation of methylthiazole and benzothiazole chromium complexes into $N$-alkyl thiazolin2-ylidene carbenes, involving deprotonation of the coordinated azole by $\mathrm{LiBu}$ and subsequent alkylation, had been previously described, ${ }^{11 c, d}$ although the experimental approach did not appear to be selective.

Transformation of compounds $\mathbf{4 a , b}$ into $\mathbf{6 a}, \mathbf{b}$ according to Scheme 2 was monitored by IR spectroscopy (see ESI $\dagger$ ). This showed a strong shift to low frequencies (about $30 \mathrm{~cm}^{-1}$ on average) in the $\nu \mathrm{CO}$ bands on passing from $\mathbf{4 a}, \mathbf{b}$ to $\mathbf{5 a}, \mathbf{b}$, and a new change to high frequencies when forming $\mathbf{6 a}, \mathbf{b}$ after protonation. The stronger donor character of the azolin-2ylidene ligands with respect to the azole tautomers is evidenced by the lower values of the $\nu \mathrm{CO}$ bands of $\mathbf{6 a}, \mathbf{b}$ with respect to 4a,b.

Amongst the spectroscopic data of compounds $\mathbf{6 a , b}(\mathrm{ESI} \dagger)$ it is worth noting the low field singlet signal appearing in the ${ }^{13} \mathrm{C}\left\{{ }^{1} \mathrm{H}\right\}$ NMR at 216.8 (6a) and 225.5 ppm (6b) corresponding to the carbene carbon atom. Fig. 2 shows the crystal structure of the cationic complex $\mathbf{6 b}$, allowing a comparison with that of<smiles>Fc1ncco1</smiles><smiles>C=CC=C</smiles>

1a<smiles>c1cscn1</smiles>

$1 b$<smiles>[C]1NC=CO1</smiles>

$2 \mathbf{a}$<smiles>C1=C[SH]=CN1</smiles>

2b
Scheme 1 Tautomerization of oxazole (1a) and thiazole (1b) molecules to 2,3-dihydrooxazol-2-ylidene (2a) and 2,3-dihydrothiazol-2ylidene (2b) carbenes, respectively. 


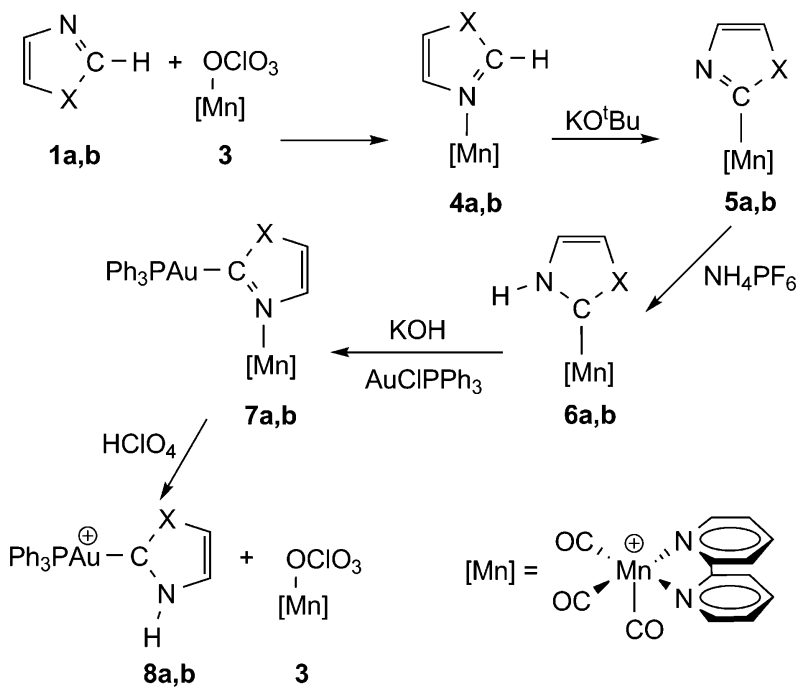

Scheme 2 Formation of azolin-2-ylidene carbene complexes of Mn(I) $\mathbf{6 a}, \mathbf{b}$ and subsequent transmetalation process to afford $\mathrm{Au}(\mathrm{I})$ carbene complexes $\mathbf{8 a}, \mathbf{b}$.

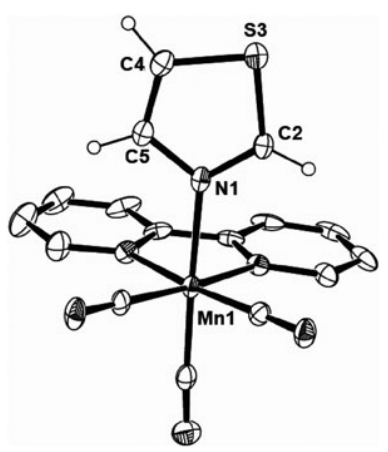

Fig. 1 Molecular structure of the complex $\mathbf{4 b}$, shown with $30 \%$ thermal ellipsoids. Hydrogen atoms of the bipy ligand are omitted for clarity. Selected interatomic distances $(\AA)$ and angles (deg): $\mathrm{Mn} 1-\mathrm{N} 1=2.074(4), \mathrm{N} 1-\mathrm{C} 2=1.321(6), \mathrm{C} 2-\mathrm{S} 3=1.691(5)$, $\mathrm{S} 3-\mathrm{C} 4=1.705(5), \quad \mathrm{C} 4-\mathrm{C} 5=1.361(7), \quad \mathrm{C} 5-\mathrm{N} 1=1.380(6) ;$ $\mathrm{Mn} 1-\mathrm{N} 1-\mathrm{C} 2=124.3(3), \mathrm{Mn} 1-\mathrm{N} 1-\mathrm{C} 5=124.9(3), \mathrm{N1}-\mathrm{C} 2-\mathrm{S} 3=114.5(3)$, $\mathrm{C} 2-\mathrm{S} 3-\mathrm{C} 4=90.3(2), \mathrm{S} 3-\mathrm{C} 4-\mathrm{C} 5=110.2(4), \mathrm{C} 4-\mathrm{C} 5-\mathrm{N} 1=114.3(4)$ $\mathrm{C} 5-\mathrm{N} 1-\mathrm{C} 2=110.7(4)$.

4b (Fig. 1). The Mn-C2 (2.024(2) $\AA$ ) bond length in $\mathbf{6 b}$ is appreciably shorter than the Mn-N1 (2.074(4) ̊) distance in $\mathbf{4 b}$, in consonance with the stronger donor character of the carbene ligand already showed in the IR data of these complexes (see above). The bond lengths and angles within the azole heterocycle are similar in both complexes, though it should be pointed out that $\mathrm{C} 5-\mathrm{N} 1-\mathrm{C} 2$ and $\mathrm{S} 3-\mathrm{C} 2-\mathrm{N} 1$ bond angles in the thiazole cycle are smaller when this features N1- (4b) and C2-coordination $(\mathbf{6 b})$, respectively.

Complexes $\mathbf{6 a}, \mathbf{b}$ can be used as carbene transfer agents from manganese to gold, in such a way that allows the isolation of heterometallic intermediates. Thus, treatment of dichloromethane solutions of $\mathbf{6 a , b}$ with a stoichiometric amount of $\left[\mathrm{AuClPPh}_{3}\right]$ in the presence of $\mathrm{KOH}$ yields complexes $\mathbf{7 a}, \mathbf{b}$ after $1 \mathrm{~h}$ of stirring at room temperature (see ESI for full experimental details $\uparrow$ ).

Complexes 7a,b contain oxazolyl and thiazolyl bridging ligands, respectively, which are C-coordinated to gold and

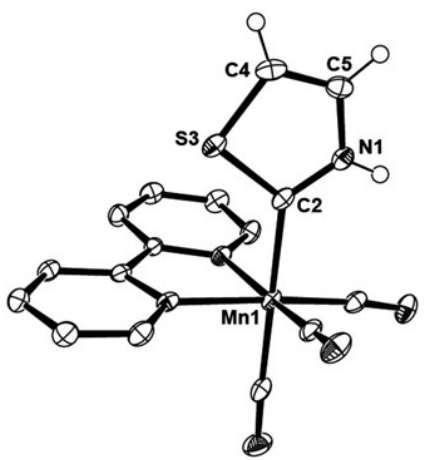

Fig. 2 Molecular structure of the complex $\mathbf{6 b}$, shown with $50 \%$ thermal ellipsoids. Hydrogen atoms of the bipy ligand are omitted for clarity. Selected interatomic distances $(\AA)$ and angles (deg): $\mathrm{Mn} 1-\mathrm{C} 2=2.024(2), \mathrm{C} 2-\mathrm{N} 1=1.333(2), \mathrm{N} 1-\mathrm{C} 5=1.387(2)$, $\mathrm{C} 4-\mathrm{C} 5=1.339(3), \mathrm{S} 3-\mathrm{C} 4=1.726(2), \mathrm{C} 2-\mathrm{S} 3=1.720(2) ;$ $\mathrm{Mn} 1-\mathrm{C} 2-\mathrm{N} 1=128.7(1), \mathrm{Mn} 1-\mathrm{C} 2-\mathrm{S} 3=124.9(1), \mathrm{C} 2-\mathrm{N} 1-\mathrm{C} 5=118.3(2)$, $\mathrm{N} 1-\mathrm{C} 5-\mathrm{C} 4=111.8(2), \mathrm{S} 3-\mathrm{C} 4-\mathrm{C} 5=109.6(1), \mathrm{C} 2-\mathrm{S} 3-\mathrm{C} 4=93.9(9)$, $\mathrm{N} 1-\mathrm{C} 2-\mathrm{S} 3=106.4(1)$.

$\mathrm{N}$-coordinated to manganese, leading uncoordinated oxygen and sulfur heteroatoms. The preference of $\mathrm{Au}(\mathrm{I})$ metal ion, which is softer than $\mathrm{Mn}(\mathrm{I})$, to bind carbene carbon atom instead of nitrogen atom appears to be the driving force for generating these heterometallic species, which can also be considered as $\mathrm{N}$-metalated azolin-2-ylidene carbene complexes of gold(I). In the case of $\mathbf{7 b}$ an X-ray diffraction study has been undertaken (Fig. 3), confirming the proposed structure for this intermediate species. The Mn-N1 bond length (2.095(2) $\AA$ ) in $7 \mathbf{b}$ is slightly longer than that in the precursor thiazole complex 4b (2.074(4) $\AA$ ), suggesting some weakening of that bond in the heterometallic intermediate, which anticipates the loss of the manganese fragment in the hydrolysis of the complex. Thus, the treatment of $\mathbf{7 b}$ with $\mathrm{HClO}_{4}$ in $\mathrm{CH}_{2} \mathrm{Cl}_{2}$ as solvent affords the gold(I) carbene complex $\mathbf{8 b}$ (Scheme 2), together with the starting manganese(I) complex $f a c-\left[\mathrm{Mn}\left(\mathrm{OClO}_{3}\right)(\mathrm{CO})_{3}(\right.$ bipy $\left.)\right]$

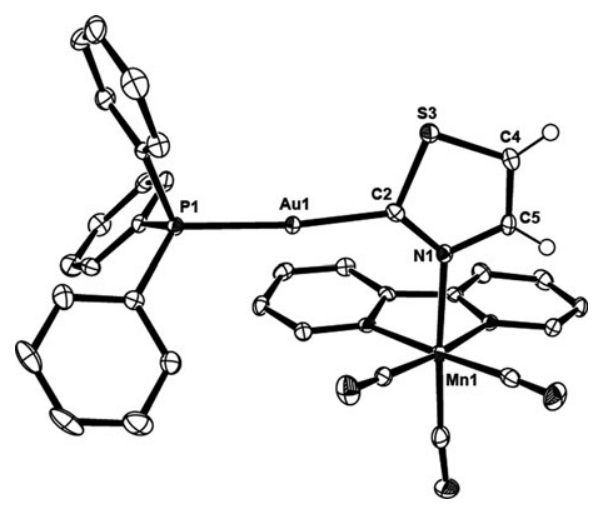

Fig. 3 Molecular structure of the complex $7 \mathbf{b}$, shown with 50\% thermal ellipsoids. Hydrogen atoms of the bipy and $\mathrm{PPh}_{3}$ ligands are omitted for clarity. Selected interatomic distances $(\AA)$ and angles (deg): Mn1-N1 = $2.095(2), \mathrm{N} 1-\mathrm{C} 5=1.390(4), \mathrm{N} 1-\mathrm{C} 2=1.336(4), \mathrm{C} 2-\mathrm{S} 3=1.742(3)$, $\mathrm{S} 3-\mathrm{C} 4=1.702(3), \mathrm{C} 4-\mathrm{C} 5=1.348(4), \mathrm{C} 2-\mathrm{Au} 1=2.040(3)$, Aul-P1 = 2.301(9); Mn1-N1-C2 = 129.5(2), Mn1-N1-C5 = 117.7(2), $\mathrm{C} 2-\mathrm{N} 1-\mathrm{C} 5=112.6(3), \mathrm{N} 1-\mathrm{C} 5-\mathrm{C} 4=115.6(3), \mathrm{N} 1-\mathrm{C} 2-\mathrm{S} 3=110.2(2)$, C2-S3-C4 = 92.4(2), S3-C4-C5 = 109.2(2), N1-C2-Au1 = 132.9(2), $\mathrm{S} 3-\mathrm{C} 2-\mathrm{Au} 1=116.9(2), \mathrm{C} 2-\mathrm{Au} 1-\mathrm{P} 1=176.4(9)$. 


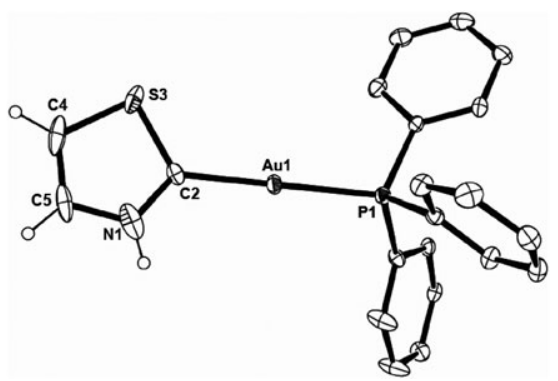

Fig. 4 Molecular structure of complex $\mathbf{8 b}$, shown with $30 \%$ thermal ellipsoids (only the major disorder component is shown). Hydrogen atoms of the bipy and $\mathrm{PPh}_{3}$ ligands are omitted for clarity. Selected interatomic distances $(\AA)$ and angles (deg): $\mathrm{C} 2-\mathrm{Aul}=2.031(7)$, $\mathrm{C} 2-\mathrm{N} 1=1.312(19), \mathrm{C} 2-\mathrm{S} 3=1.714(8), \mathrm{S} 3-\mathrm{C} 4=1.715(11)$, $\mathrm{C} 4-\mathrm{C} 5=1.348(17), \mathrm{N} 1-\mathrm{C} 5=1.370(20), \mathrm{Au} 1-\mathrm{P} 1=2.283(1)$; $\mathrm{C} 2-\mathrm{Au} 1-\mathrm{P} 1=177.6(3), \mathrm{Au} 1-\mathrm{C} 2-\mathrm{N} 1=127.6(1), \mathrm{Au} 1-\mathrm{C} 2-\mathrm{S} 3=124.1(4)$, $\mathrm{N} 1-\mathrm{C} 2-\mathrm{S} 3=108.3(1), \mathrm{C} 2-\mathrm{S} 3-\mathrm{C} 4=91.9(5), \mathrm{S} 3-\mathrm{C} 4-\mathrm{C} 5=111.0(6)$, C4-C5-N1 = 110.5(1), C2-N1-C5 = 118.2(2).

(3), completing the transmetalation process of carbene $\mathbf{2} \mathbf{b}$ from manganese to gold. ${ }^{14}$ The crystal structure of $\mathbf{8 b}$ (Fig. 4) shows no significant differences in the structural parameters of the heterocyclic carbene with respect to those in complex $\mathbf{7 b}$.

In conclusion, we report herein an experimental approach for the synthesis of oxazolin-2-ylidene and thiazolin-2-ylidene carbene complexes of manganese(I) involving tautomerization of the corresponding oxazole and thiazole heterocycles mediated by the metal center. The new carbene ligands can be transferred to gold(I) through isolable heterometallic intermediates. Experiments aiming to make use of complexes $\mathbf{6 a}, \mathbf{b}$ as carbene transfer agents to other metallic centers are currently in progress in our laboratory.

Acknowledgement is made to the Spanish Ministerio de Ciencia e Innovación for financial support (PGE and FEDER funding, Project CTQ2006-10035). B. F. P. thanks the MICINN for an FPU grant (PGE and European Social Fund).

\section{Notes and references}

$\ddagger$ Crystal data for $4 \mathbf{b}: \mathrm{C}_{17} \mathrm{H}_{13} \mathrm{Cl}_{3} \mathrm{MnN}_{3} \mathrm{O}_{7} \mathrm{~S}, M=564.66$, monoclinic, $P 21 / n, a=10.1874(5), b=12.8131(5), c=16.3439(7) \AA, \beta=93.621(2)^{\circ}$, $V=2129.15(16) \AA^{3}, Z=4, T=100(2) \mathrm{K}, 33014$ measured reflections, 3647 independent reflections $\left(R_{\text {int }}=0.0672\right), R 1=0.0755, \mathrm{w} R 2=0.2284$ (all data). 6b. $\mathrm{C}_{16} \mathrm{H}_{11} \mathrm{~F}_{6} \mathrm{MnN}_{3} \mathrm{O}_{3} \mathrm{PS}, \quad M=525.25$, triclinic, $P \overline{1}$, $a=8.6199(3), b=10.0390(3), c=11.5074(3) \AA, \alpha=78.487(1)$, $\beta=80.485(2), \gamma=84.597(2)^{\circ}, V=960.41(5) \AA^{3}, Z=2, T=100(2) \mathrm{K}$, 15455 measured reflections, 3416 independent reflections $\left(R_{\text {int }}=0.0275\right)$, $R 1=0.0338, w R 2=0.0648$ (all data). $7 \mathbf{b ~} \mathrm{C}_{34} \mathrm{H}_{25} \mathrm{AuF}_{6} \mathrm{MnN}_{3} \mathrm{O}_{3} \mathrm{P}_{2} \mathrm{~S}$, $M=983.48$, triclinic, $P \overline{1}, a=11.0938(3), b=11.4700(4)$, $c=15.1096(5) \AA, \alpha=94.041(2), \beta=101.191(2), \gamma=112.355(2)^{\circ}$, $V=1722.13(10) \AA^{3}, Z=2, T=100(2) \mathrm{K}, 57416$ measured reflections, 6738 independent reflections $\left(R_{\text {int }}=0.0305\right), R 1=0.0398$, $\mathrm{w} R 2=0.0519$ (all data). 8b $\mathrm{C}_{21} \mathrm{H}_{18} \mathrm{AuClNO}_{4} \mathrm{PS}, M=643.81$, monoclinic, $P 21 / n, a=9.7030(3), b=16.6091(6), c=13.9180(4) \mathrm{A}$, $\beta=101.338(2)^{\circ}, V=2199.22(12) \AA^{3}, Z=4, T=100(2) \mathrm{K}, 57620$ measured reflections, 4051 independent reflections $\left(R_{\text {int }}=0.0314\right)$, $R 1=0.0516, \mathrm{w} R 2=0.0658$ (all data).
1 M. M. Campell, in Comprehensive Organic Chemistry, ed. D. Barton, W. D. Ollis and P. G. Sammes, Pergamon Press, Oxford, 1979, vol. 4, pp. 961-993; F. W. Hartner, Jr, in Comprehensive Heterocyclic Chemistry II, ed. I. Shinkai, Elsevier, Oxford, 1996, vol. 3, pp. 261-318; A. Dondoni and P. Merino, in Comprehensive Heterocyclic Chemistry II, ed. I. Shinkai, Elsevier, Oxford, 1996, vol. 3, pp. 373-474; M. G. Saulnier, U. Velaparthi and K. Zimmermann, Prog. Heterocycl. Chem., 2004, 16, 228; S. Cicchi, F. M. Cordero and D. Giomi, Prog. Heterocycl. Chem., 2003, 15, 261.

2 F. Freeman, D. J. Lau, A. R. Patel, P. R. Pavia and J. D. Willey, J. Phys. Chem. A, 2008, 112, 8775; M. Cheng and C. Hu, Tetrahedron Lett., 2001, 42, 3897; G. A. McGibbon, J. Hrusák, D. J. Lavorato, H. Schwarz and J. K. Terlouw, Chem.-Eur. J., 1997, 3, 232.

3 T. L. Amyes, S. T. Diver, J. P. Richard, F. M. Rivas and K. Toth, J. Am. Chem. Soc., 2004, 126, 4366.

4 G. Maier, J. Endres and H. P. Reisenauer, Angew. Chem., Int. Ed. Engl., 1997, 36, 1709.

5 For recent reviews, see F. E. Hahn and M. C. Jahnke, Angew. Chem., Int. Ed., 2008, 47, 3122; R. H. Crabtree, Coord. Chem. Rev., 2007, 251, 595; R. W. Alder, M. E. Blake, L. Chaker, J. N. Harvey, F. Paolini and J. Schütz, Angew. Chem., Int. Ed., 2004, 43, 5896; A. J. Arduengo, III, Acc. Chem. Res., 1999, 32, 913; D. Bourissou, O. Guerret, F. P. Gabaï and G. Bertrand, Chem. Rev., 2000, 100, 39.

6 W. A. Hermann, Angew. Chem., Int. Ed., 2002, 41, 1290; $\mathrm{N}$-Heterocyclic Carbenes in Transition Metal Catalysis Top. Organomet. Chem., ed. F. Glorius, Springer, Berlin, 2007, vol. 21.

7 U. Kernbach, T. Lügger, F. E. Hahn and W. P. Fehlhammer, J. Organomet. Chem., 1997, 541, 51; R. Fränkel, U. Kernbach, M. Bakola-Christianopoulou, U. Plaia, M. Suter, W. Ponikwar, H. Nöth, C. Moinet and W. P. Fehlhammer, J. Organomet. Chem., 2001, 617-618, 530; M. Tamm and F. E. Hahn, Coord. Chem. Rev., 1999, 182, 175; R. A. Michelin, A. J. L. Pombeiro and M. F. C. Guedes da Silva, Coord. Chem. Rev., 2001, 218, 75; F. E. Hahn and M. Tamm, J. Chem. Soc., Chem. Commun., 1995, 569; J. Barluenga, F. Aznar, B. Weyershausen, S. García-Granda and E. Martín, Chem. Commun., 1996, 2455.

8 U. Belluco, R. A. Michelin, R. Ros, R. Bertani, G. Facchin, M. Mozzon and L. Zanotto, Inorg. Chim. Acta, 1992, 198-200, 883; W. P. Fehlhammer and M. Fritz, Chem. Rev., 1993, 93, 1243; R. Kunz, P. L. Grel and W. P. Fehlhammer, J. Chem. Soc., Dalton Trans., 1996, 3231.

9 C. Tubaro, A. Biffis, M. Basato, F. Benetollo, K. J. Cavell and L. Ooi, Organometallics, 2005, 24, 4153.

10 V. Langenhahn, G. Beck, G. Zinner, D. Lentz, B. Herrschaft and W. P. Fehlhammer, J. Organomet. Chem., 2007, 692, 2936.

11 (a) H. G. Raubenheimer, F. Scott, S. Cronje, P. H. van Rooyen and K. Psotta, J. Chem. Soc., Dalton Trans., 1992, 1009; (b) H. G. Raubenheimer, A. Neveling, S. Cronje and D. G. Billing, Polyhedron, 2001, 20, 1089; (c) H. G. Raubenheimer, Y. Stander, E. K. Marais, C. Thompson, G. J. Kruger, S. Cronje and M. Deetlefs, J. Organomet. Chem., 1999, 590, 158; (d) H. G. Raubenheimer, G. J. Kruger, A. van A. Lombard, L. Linford and J. C. Viljoen, Organometallics, 1985, 4, 275; (e) H. G. Raubenheimer and S. Cronje, J. Organomet. Chem., 2001, 617-618, 170; (f) H. G. Ruabenheimer, F. Scott, G. J. Kruger, J. G. Toerien, R. Otte, van Zyl, I. Taljaard, P. Olivier and L. Linford, J. Chem. Soc., Dalton Trans., 1994, 2091.

12 G. C. Vougioukalakis and R. H. Grubbs, J. Am. Chem. Soc., 2008, 130, 2234.

13 J. Ruiz and B. F. Perandones, J. Am. Chem. Soc., 2007, 129, 9298.

14 The oxazolin-2-ylidene carbene complex of gold(I) 8a is formed from 7a in a similar way, as detected by NMR spectroscopy, through in this case purification of the compound was not feasible owing to the appearance of variable amounts of secondary products. 